\title{
Geological Conditions of Shale Gas Accumulation of Yanghugou Formation in Western Margin of Ordos Basin
}

\author{
Chongjing Wang ${ }^{1, a}$, He Zhang ${ }^{2, b}$ \\ ${ }^{1,2}$ China University of Mining and Technology, Beijing 100083, China \\ awangchongjing1987@163.com, ${ }^{\mathrm{b}}$ zhanghe92@163.com
}

Keywords: Yanghugou Formation; shale gas accumulation; thrust nappe structure; TOC; $\mathrm{R}_{\mathrm{o}}$.

\begin{abstract}
Dark shale and silty mudstone are rich in Yanghugou Formation. The thrust nappe moments, popularly developed in study areas, may lead to form thick-layer shale. Geological conditions are good for shale gas accumulation as follows: firstly, the main type of organic kerogen is III, and type II-I, hydrocarbon generation are very strong, also exist, secondly, the thick dark shale, thirdly, the high TOC value and the high degree of thermal evolution of organic matter, at last, the favorable preservation conditions. After studying these conditions, this paper comes to the conclusion that such areas are the most beneficial for shale gas accumulation in Yanghugou Formation: southern Hulusitai, Wuda and Shitanjing.
\end{abstract}

\section{Introduction}

Shale gas mainly store in dark shale or high carbon shale and mainly exist in adsorption or free state, and it reserved in interlaid siltstone, silty mudstone, argillaceous siltstones and even sandstone in rock stratum., which nearby accumulate in source rock strata after hydrocarbon generation. It is typical in-situ reservoir forming mode. By definition, many differences identified by comparison with conventional gas. For one thing, shale gas is generally blocked up in hydrocarbon source rocks instead of migrating. For another, adsorption gas usually account for more than 50\%, which determine it hold strong anti-tectonic destruction capability [1]. Yanghugou Formation is marine-continental transitional facies sedimentation.

The western margin of Ordos Basin is approximately a north-south narrow zone between Alashan Block and Ordos Basin, including northern Helan-Zhuozi Mountain and southern Zhongwei-Zhongning areas. The Ordos Basin is the second largest sedimentary basin in China with multi-type and multilayer source beds, and the present oil-gas resources and reserves are evidently at odds with its scale and deposition volume. The natural gas distribution regularity is still unknown in the whole basin, especially the western margin. Yanghugou Formation is the Late Paleozoic strata well developed with hydrocarbon source rock in the west basin . It holds the feature of synchronous-heteropic sedimentary with Benxi Formation. In order to master the shale gas accumulation of Yanghugou Formation, this paper discusses from the following aspects: (1) the depositional environment ;(2) the stratigraphic features;(3) the geochemical characteristics.

\section{Sedimentary Environment and Shale Development}

The sedimentary environment. North China Sea and Qilian Sea were divided by central palaeo-uplift in Late Carboniferous. When North China Sea westward overlapped, Benxi Formation developed in epicontinental basin with widely distributed feature. At the same time, Yanghugou coal-bearing stratum deposited in Qilian Sea with the different feature of thick dark shale of marine-continental transitional facies. Then, the transgression enlarged both of the two seas. At last, the whole basin entered unified evolution stage and Taiyuan Formation integration distributed on Yanghugou Formation or Benxi Formation of Ordos basin [2]. In study area, Late Carboniferous stratum basically share the same feature with north qilian area, but different from Ordos basin. Plant fossil assemblage can also certify the phenomenon. Europe and America flora and Cathaysian flora belong to Yanghugou Formation and Benxi Formation, while Taiyuan Formation charactered 
Cathaysian flora in the whole basin. So Yanghugou Formation and Benxi Formation are geared to synchronous-heteropic sedimentary.

The development of dark shale. It is the eastward transgression deposition of Qilian sea, which based on Jingyuan Formation with filling up characteristics. The lithologic compositions are dark shale , silty mudstone and thin-layered off white fine sandstone, lipoclastic micrite limestone and coal streak. The very developed giant thickness dark shale, through coal bed not development, provides excellent conditions for shale gas development.

The aulacogen, basement subsided slowly, revived in study area with the background of east west direction extension. In the areas of Wuda, Hulusitai and Queergou, Yanghugou Formation has structural features of down warping type depression. It is regional unconformity boundary of Yanghugou Formation and the Early Carboniferous strata. The amplitude imbalance settlement leaded to the sedimentary thickness very difference, which from tens to thousands meters thickness. It can be seen from profile that there two subsiding centers. The Northern subsiding center is located in a gleam of Hulusitai-Wuda and the Southern subsiding center is located in a gleam of Queergou-Shizuishan, which the Shabatai rise between them.The thickness of Wuda, close to $1000 \mathrm{~m}$, is the thickest, Queergou is more than 600m, and Hulusitai is more than 500m,but Shabatai is only $200 \mathrm{~m}$, which lack the lower member.

As seen in Table 2, the most development places of mark mudstone of Yanghugou Formation are listed: Wuda, Hulusitai, Shitanjing, etc. And its shale-stratum ratio exceeds $60 \%$. Single layer shale are mostly thicker than sandstone, and the thickest section of monolayer shale observed in Hulusitai is $28.66 \mathrm{~m}$. Thrust nappe structure develops in study area, and stacked strata can be observed easily. It is very common to observe that two sets of thick shale Formation overlapped. These conditions are favorable for shale gas accumulation. Besides, when stratum overlapped for thrust nappe structure, the lower one is better for accumulation and preservation of shale gas than the upper one. Because shale Formation has strong heat insulation property, the lower segment has higher level of evolution of organic and is more beneficial for shale to generate hydrocarbon.

Table 2 The rock type and abundance of Yanghugou formation

\begin{tabular}{c|c|c|c|c|c}
\hline Area & Total thickness & Sandstone & Shale & Limestone & Coal seam \\
\hline Zhuozishan & $25.03 \mathrm{~m}$ & $19.44 \mathrm{~m}$ & $5.41 \mathrm{~m}$ & $0.07 \mathrm{~m}$ & $0.11 \mathrm{~m}$ \\
Hulusitai & $447.44 \mathrm{~m}$ & $160.31 \mathrm{~m}$ & $275.54 \mathrm{~m}$ & $11.34 \mathrm{~m}$ & - \\
Wuda & $748.3 \mathrm{~m}$ & $256.2 \mathrm{~m}$ & $489.3 \mathrm{~m}$ & - & $2.8 \mathrm{~m}$ \\
Shitanjing & $531.96 \mathrm{~m}$ & $185.54 \mathrm{~m}$ & $339.57 \mathrm{~m}$ & $4.9 \mathrm{~m}$ & $1.95 \mathrm{~m}$ \\
Hengcheng & $172.14 \mathrm{~m}$ & $53.28 \mathrm{~m}$ & $111.32 \mathrm{~m}$ & $4.67 \mathrm{~m}$ & $2.87 \mathrm{~m}$ \\
Weizhou & $222.15 \mathrm{~m}$ & $123.78 \mathrm{~m}$ & $97.43 \mathrm{~m}$ & $0.95 \mathrm{~m}$ & $0.13 \mathrm{~m}$ \\
Pingliang & $19.15 \mathrm{~m}$ & $10.6 \mathrm{~m}$ & $8.55 \mathrm{~m}$ & - & - \\
\hline
\end{tabular}

\section{Characteristics of Tectonic Evolution}

Tectonic framework .Western Ordos Basin is in the transition zone of Chian eastern-western tectonic domains. Affected by the complex plate tectonics, tectonic movement in western Ordos is quite well developed. Complex structure resulted from Caledonian, Hercynian, Indo-China, and Himalayan tectonic movements. Thrust nappe structure, also an important reason thick dark shale, is well-developed in study area. [3].

However, geological features are quite different and incongruent. A good illustration are the tectonic differences between Majiatan and Hengshanbao. So there is no unified pattern in the whole region. The fractures would be bad for shale gas preservation, but other factors may ensure the preservation good. Free gas and absorption gas compose the shale gas .So it hold relatively strong resistance against tectonic destruction for adsorption. Besides, the upper coal-bed give good condition for gas preservation, and the relatively soft mudstone smear the cracks. All the above contribute to the generally good preservation conditions for shale gas in study region.

The tectonic evolution history. Different local areas in study region have undergone several different uplifts and subsidence in various times and stages. Northern Rujigou probably has 
undergone at least two uplifts that occurred in late Cretaceous and Eocene and a slight uplift in late Jurassic; Central Shigouyi has witnessed two uplift-related cooling events happened in late Jurassic and late Cretaceous; The two main uplifts in the entire southern area occurred in late Jurassic and early Cretaceous-late Cretaceous. A rapid uplift in Liupanshan Mountain occurred at the end of Miocene. Different areas developed quite unevenly. The uplift generally occurred earlier in southern areas than that in northern areas. The uplifted strata would stop the hydrocarbon generation. The strata might erode or the preservation conditions might be deteriorated if the strata were uplifted to the surface or the near-surface [4]. Besides, many former researchers have found that there were strong tectonic thermal events in Ordos Basin at the end of late Jurassic. The thermal event timing is $124 \sim 153 \mathrm{Ma}$. The thermal event resulted from mantle creeping movement. And this also contributes a lot to the overall-high maturity of the organic matter evolution despite of the several tectonic uplifts in the study region.

\section{Hydrocarbon generation capacity of dark shale}

The organic matter type .The organic matter type of source rocks in Yanghugou Formation mainly consists of terrestrial humus. The kerogen type is typical III which is rich in high ability of gas generation vitrinite.

Besides, some parts of lower aquatic plants can be found in deep-water, in which kerogen type is II-I, Hydrogen-rich vitrinite develops in these organic matter, which hold high ability of hydrocarbon generation. Type II-I kerogen not only has ability to generate liquid hydrocarbon but also generate gas hydrocarbon as the Ro increasing. Both the intensity and total quality of Hydrocarbon generation are greater than type-III kerogen. So the quality of Yanghugou Formation is better other upper stratum of the Paleozoic with type-III kerogen.

The organic matter abundance. The Yanghukou Formation organic-rich shale in study area was formed by the marine-terrigenous fancies of Qilian sea area in the late of carboniferous. Not only did it have large shale thickness, but also high abundance of organic matter. Characterized by high TOC, high chloroform bitumen " $\mathrm{A}$ ”,HC, and low organic conversion rate(chloroform bitumen “A”/C、HC/C), The average of shale TOC is 3.25\% (As Fig.2 a), while TOC and shale gas content were positively correlated with each other (As Fig.2 b) [1]. Exinite and no fix body develop in Yanghugou Formation, which has stronger ability of hydrocarbon generation. It hold high numerical value of $\mathrm{S}_{1}+\mathrm{S}_{2}: 3.62 \mathrm{mg} / \mathrm{g}$ in Hulusitai, $1.28 \mathrm{mg} / \mathrm{g}$ in Wuda, $4.33 \mathrm{mg} / \mathrm{g}$ in Bacan well 2, and the high value of $27.12 \mathrm{mg} / \mathrm{g}$ in high carbon mudstone, which all reach the standard of well gas source rock.

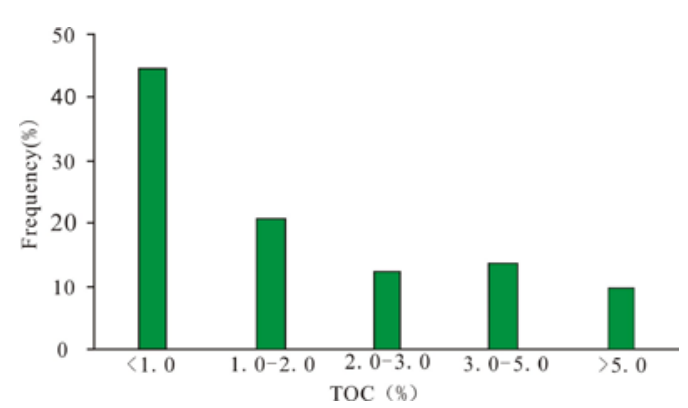

(a)

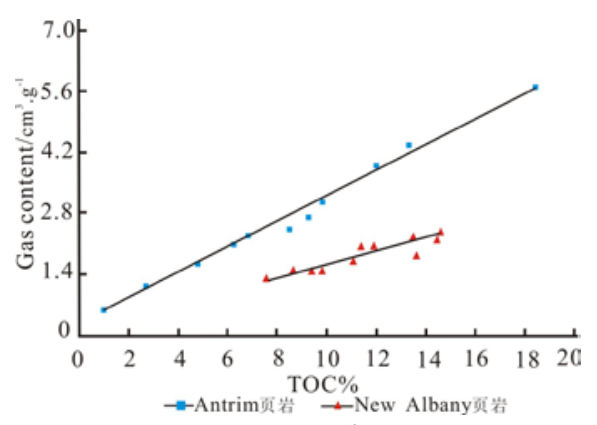

(b)

Fig 2 TOC and the relationship between gas content and TOC

The thermal evolution degree of organic matter. It is overall high and complex, but regularity and directivity are not obvious. Generally, the trend is north-South high and middle low. It doesn't accord with the plutonic metamorphism law in study area, which shows that something may affect the process of thermal evolution of organic matter. For example, the areas, south of Hulusitai and Maliantan, get high degree of thermal evolution of organic matter caused by the concealed rock mass in Rujigou. The higher degree of Weizhou (Ro>4.0\%) may be effected by magmatism. However, Stratum uplift resulted from Indo-china movement or early Yanshan movement lead to relatively low degrees in some areas, such as Wuhai and northeast of Shitanjing-Hulusitai. In 
summary, the degree of thermal evolution of organic matter may result from both plutonic metamorphism and magmatic thermal metamorphism. The complex degrees come from the results that developments of magmatic metamorphism during the stratum uplift which caused by multi-phase tectonic movement in study area.

\section{Conclusions}

By comparing favorable area parameters with dark shale of Yanghugou Formation in study area, $\mathrm{t}$ the parameters meet the conditions. So we can come to the following conclusions :(1) The depocenters of Wuda and Queergou , the dark shale is very thick, get the shale-stratum ratio exceeds 60 . The overlapped shale Formation caused by thrust nappe structure can be found easily. These conditions are beneficial to shale gas accumulation and exploitation; (2) Shale gas accumulates in source rock. Through faults developing, the preservation conditions are good for shale gas because of the comprehensive results, such as shale adsorption, sealed by shale-smear and extensive coal bed, etc;(3) The degree of thermal evolution of organic matter is overall high and complex, but regularity and directivity are not obvious. It may result from both plutonic metamorphism and magmatic thermal metamorphism. The high degree is good for shale gas accumulation, which not only because of high hydrocarbon generation capacity, but also more space coming from organic matter hydrocarbon generation for gas accumulation;(4) According to many aspects on compressive research, geological conditions for shale gas accumulation in Yanghugou Formation are favorable, especially in southern Hulusitai, Wuda and Shitanjing.

\section{References}

[1] J.C.Zhang,H.Xue, and D.M.Zhang:J. Modern geology, Vol. 17(4) (2003), p.466.

[2] G.S.Zhang,J.Zhang,X.Wang:J. Natural gas industry, Vol.25(4) (2005),p.19.

[3] P.K.Zhao,Y.L.Ji:J. Xinjiang Geology, Vol.23(2) (2005),p.155.

[4] S.J.Wang,D.H.Li,J.Z.Li:J. Natural gas industry, Vol.31(12) (2011),p.45. 